\title{
PERTANIAN
}

\section{PENGARUH PENGGUNAAN PUPUK ORGANIK KASCING DAN HORMON GIBERELIN (GA3) TERHADAP PRODUKSI DAN KUALITAS BUAH MENTIMUN (Cucumis sativus L.)}

\author{
The Effect of Using Vermicompost Organic Fertilizer and Giberelin Hormone ( $\left.G A_{3}\right)$ \\ On the Production and Quality of Cucumber Fruit (Cucumis Sativus L.)
}

\author{
Ayna Devita Trisna Putri dan Miswar*
}

\author{
Program Studi Agroteknologi, Fakultas Pertanian, Universitas Jember, \\ Jalan Kalimantan No. 37 Kampus Tegalboto, Sumbersari, Jember, 68121 \\ *E-mail: mmiswar20@gmail.com
}

\begin{abstract}
Cucumber is a horticultural product which becomes one type of fruit vegetable and has a great demand in the community. The potential productivity of cucumber itself is still relatively low, that is in 2016 amounting to 10.19 tons / ha, this also occurs in the productivity of local cucumbers which are quite low, but until now there are still many cultivated by farmers in Jember area. In addition to the increase in production, it is also necessary to improve the quality of fruit which affects the competitiveness of the selling value of cucumber fruit. Regarding the increase in production and quality of fruit, the efforts need to be made to improve cultivation methods. One of them is the use of organic fertilizers which contain more complex nutrients and the application of plant regulators. One of the organic fertilizers, vermicompost organic fertilizer, is the result of decomposition by worms which affects plant growth and the application of gibberellins (GA3), it can improve fruit quality and increase the percentage of fruit formation. This study aimed to determine the effect of using the combination of vermicompost organic fertilizer and the addition of giberelin (GA3) on cucumber plants by using a randomized group design (RGD) with 2 factors and 3 replications. The first factor was giving vermicompost organic fertilizer, namely (K0) $0 \mathrm{~g} / \mathrm{plant}$ (control), (K1) 120 g/plant (3 tons/ha), (K2) $240 \mathrm{~g} /$ plant (6 tons/ha), (K3) $360 \mathrm{~g} / \mathrm{plant}$ (9 tons/ha). The second factor was the addition of gibberellin concentrations (GA3), namely (G0) 0 ppm, (G1) $50 \mathrm{ppm}$, (G2) $100 \mathrm{ppm}$ and (G3) $150 \mathrm{ppm}$. The data obtained were then analyzed using variance analysis, if between treatments had a significant difference, then further tests were carried out by using Duncan's Multiple Distance Test at the level of 5\%. The best treatment ofvermicompost organic fertilizer dosage and giberelin hormone concentration was found in the treatment of $360 \mathrm{~g} / \mathrm{plant}$ or 9 tons/ha (K3) at the optimal concentration of $100 \mathrm{ppm}$ giberelin hormone.
\end{abstract}

Key words: Cucumber, Vermicompost fertilizer, Gibberellin $\left(\mathrm{GA}_{3}\right)$, Production and Quality of Fruit

\begin{abstract}
ABSTRAK
Mentimun merupakan produk hortikultura yang menjadi salah satu jenis sayuran buah yang banyak diminati oleh masyarakat. Potensi produktivitas mentimun sendiri masih tergolong rendah yaitu pada tahun 2016 sebesar 10,19 ton/ha, hal ini juga terjadi pada produktivitas mentimun jenis lokal yang cukup rendah, namun sampai saat ini masih banyak dibudidayakan oleh petani pada daerah Jember. Selain peningkatan terhadap produksi, perlu juga dilakukan perbaikan kualitas buah yang berpengaruh pada daya saing nilai jual buah mentimun. Terkait peningkatan produksi dan mutu buah, maka perlu dilakukan upaya perbaikan cara budidaya. Salah satunya adalah penggunaan pupuk organik yang mengandung unsur hara yang lebih kompleks dan pengaplikasian zat pengatur tumbuhan. Salah satu pupuk organik yaitu pupuk organik kascing, yang merupakan hasil dekomposisi oleh cacing yang berpengaruh terhadap pertumbuhan tanaman dan aplikasi giberelin $\left(\mathrm{GA}_{3}\right)$ yang mampu meningkatkan kualitas buah dan meningkatkan persentase pembentukan buah. Penelitian ini bertujuan untuk mengetahui pengaruh kombinasi penggunaan pupuk kascing dan pemberian hormon giberelin $\left(\mathrm{GA}_{3}\right)$ pada tanaman mentimun, menggunakan Rancangan Acak Kelompok (RAK) dengan 2 faktor dan 3 ulangan. Faktor pertama pemberian dosis pupuk kascing yaitu, (K0) 0 g/tanaman (kontrol), (K1) $120 \mathrm{~g} / \operatorname{tanaman}$ (3 ton/ha), (K2) $240 \mathrm{~g} / \operatorname{tanaman}(6 \mathrm{ton} / \mathrm{ha})$, (K3) $360 \mathrm{~g} / \operatorname{tanaman}$ (9 ton/ha). Faktor kedua pemberian konsentrasi giberelin $\left(\mathrm{GA}_{3}\right)$ yaitu $(\mathrm{G} 0) 0 \mathrm{ppm},(\mathrm{G} 1) 50 \mathrm{ppm},(\mathrm{G} 2) 100 \mathrm{ppm}$ dan $(\mathrm{G} 3) 150 \mathrm{ppm}$. Data yang diperoleh selanjutnya dianalisis menggunakan analisis sidik ragam, jika antar perlakuan mengalami perbedaan yang signifikan, maka dilakukan uji lanjut dengan menggunakan Uji Jarak Berganda Duncan pada taraf 5\%. Perlakuan dosis pupuk kascing dan konsentrasi hormon Giberelin terbaik terdapat pada perlakuan $360 \mathrm{~g} / \operatorname{tanaman}$ atau 9 ton/ha (K3) pada konsentrasi optimal hormon giberelin $100 \mathrm{ppm}$.
\end{abstract}

Kata Kunci: Mentimun, Pupuk Kascing, Giberelin $\left(\mathrm{GA}_{3}\right)$, Produksi dan Kualitas Buah

How to citate: Putri, A.D.T. dan Miswar. 2019. Pengaruh Penggunaan Pupuk Organik Kascing dan Hormon Giberelin $\left(\mathrm{GA}_{3}\right)$ Terhadap Produksi dan Kualitas Buah Mentimun. Berkala Ilmiah Pertanian 2(3): 102-107. 


\section{PENDAHULUAN}

Mentimun (Cucumis sativus L.) merupakan salah satu komoditas tanaman hortikultura yang dapat dibudidayakan pada daerah tropis maupun sub tropis. Menurut data Direktorat Jendral Hortikultura (2014), produktivitas mentimun secara nasional mengalami fluktuasi dari tahun 2012 - 2016 yaitu sebesar 9,97 ton/ha; 9,97 ton/ha; 9,84 ton/ha, 10,27 ton/ha dan 10,19 ton/ha. Menurut Abdurrazak dkk. (2013), produksi buah mentimun masih tergolong rendah yaitu hanya berkisar 10 ton/ha. Beberapa jenis mentimun telah banyak berkembang di Indonesia salah satunya adalah mentimun lokal. Salah satu jenis mentimun lokal yang banyak dibudidayakan di daerah Jember adalah jenis mentimun Wuku. Hasil mentimun pada daerah Kabupaten Jember, memiliki rata-rata hasil yang masih cukup rendah yaitu berkisar 15-17 ton/ha, sedangkan potensi hasil mentimun Wuku bisa mencapai 49 ton/ha. Selain itu, salah satu masalah yang ditemui pada tanaman mentimun Wuku persentase bunga yang mampu menjadi buah sempurna, bunga betina yang mampu berkembang menjadi buah hanya mencapai $\pm 60 \%$.

Perbaikan terhadap kualitas dari buah mentimun juga perlu terus dilakukan peningkatan baik dari segi ukuran buah, rasa, warna dan ketebalan daging buah, hal ini bertujuan untuk meningkatkan daya saing produk buah mentimun, dimana untuk kualitas buah mentimun Wuku masih rendah yaitu masih banyaknya buah-buah yang terbentuk abnormal sehingga tidak memenuhi kualitas permintaan pasar atau konsumen. Ukuran dan mutu buah mentimun yang ideal yaitu memiliki ukuran garis tengah 2,5-4,0 cm, panjang buah $\pm 15-20 \mathrm{~cm}$ dan berat dalam satu kilogram antara 6-7 buah.

Pemupukan merupakan salah satu kegiatan pemeliharaan yang memiliki pengaruh yang cukup besar terhadap hasil tanaman secara optimal. Teknik budidaya mentimun secara konvensional masih menjadi cara yang banyak dipilih oleh petani, dimana penggunaan input pupuk kimia anorganik masih cukup tinggi. Penggunaan pupuk kimia anorganik secara terus menerus dapat menyebabkan tanah menjadi lebih keras, pencemaran lingkungan dan hasil panen yang mudah rusak (Susanto dalam Permanasari dan Annisava, 2015). Peningkatan produktivitas dapat dilakukan dengan efisiensi pemupukan yaitu mengurangi pemberian pupuk anorganik yang berlebihan namun tingkat kesuburan dan unsur hara tanaman tetap terjaga yaitu dengan cara penyediaan bahan organik.

Salah satu pupuk organik yang dapat digunakan adalah pupuk kascing atau vermikompos. Menurut Simanullang dkk (2014), kascing adalah pupuk yang berasal dari kotoran cacing (Lumbricus rubellus), yang mengandung unsur hara makro dan mikro, seperti Nitrogen (N), Fosfor (P), Kalsium (K), Belerang (S), Magnesium ( $\mathrm{Mg}$ ), Besi $(\mathrm{Fe})$ dan Kalium (Ca) selain itu juga mengandung beberapa hormon pertumbuhan seperti auksin, giberelin dan sitokinin. Keuntungan lainnya dari pupuk kascing yaitu kaya akan mikroorganisme untuk mengoptimalkan pertumbuhan tanaman, kaya akan asam humat yang berguna untuk pemajangan akar sehingga dapat meningkatkan serapan hara oleh tanaman. Pengaplikasian pupuk kascing memiliki efek terhadap peningkatan pertumbuhan tanaman, proses pembungaan dan hasil buah yang lebih optimal pada tanaman padi, buah dan sayuran (Thiruneelakandan dan Subbulakshmi dalam Londe dan Bhosale, 2015).

Selain dilakukannya pemenuhan terhadap unsur hara untuk tanaman, pengaplikasian hormon juga penting untuk memacu proses fisiologi tanaman. Salah satu hormon yang dapat memacu pertumbuhan dan perkembangan tanaman adalah hormon giberelin $\left(\mathrm{GA}_{3}\right)$. Penggunaan giberelin mendukung pembentukan enzyme protolitic yang membebaskan tryptophan sebagai asal bentuk dari auxin. Giberelin juga mendukung pengembangan dinding sel. Giberelin yang diaplikasikan saat awal berbunga berperan dalam proses penggiatan pembungaan serta menurunkan absisi bunga maupun buah, sedangkan $\mathrm{GA}_{3}$ yang diaplikasikan saat awal berbuah mampu meningkatkan jumlah buah yang terbentuk. Kombinasi perlakuan waktu aplikasi saat berbunga dan berbuah dengan konsentrasi $100 \mathrm{ppm}$ menunjukkan persentase fruit set lebih tinggi dibandingkan tanpa perlakuan hormon giberelin pada persentase fruit set pada tanaman cabai besar (Yasmin dkk., 2014). Hormon giberelin juga berpengaruh terhadap jumlah biji yang dihasilkan, ukuran dan bobot buah. Berdasarkan hasil penelitian, pengaplikasian hormon giberelin sekitar 150-200 ppm mampu meningkatkan bobot buah dan mengurangi jumlah biji pada buah mentimun (Wulandari dkk., 2014). Oleh karena itu diperlukan penelitian mengenai pengaruh kombinasi pupuk organik kascing dan konsentrasi hormon giberelin terhadap produksi dan kualitas buah mentimun.

\section{BAHAN DAN METODE}

Waktu dan Tempat.Penelitian dilaksanakan pada bulan Juli 2018 sampai dengan September 2018, Bertempat di Desa Wonorejo, Kecamatan Banyuputih, Kabupaten Situbondo.

Bahan dan Alat. Bahan tanam yang dipergunakan adalah mentimun varietas Wuku, pupuk yang dipergunakan terdiri dari pupuk organik kascing dan pupuk anorganik (ZA, SP-36, KCl), hormon giberelin $\left(\mathrm{GA}_{3}\right) 20 \%$, pestisida Demolish, fungsida. Alat yang digunakan pada kegiatan penelitian ini yaitu timbangan analitik, jangka sorong, penggaris, sprayer, polybag $(30 \times 30 \mathrm{~cm})$, gelas ukur, kamera, alat penunjang untuk analisis tanah dan pupuk, alat - alat tulis dan lain lain.

Rancangan Percobaan. Percobaan ini disusun secara faktorial menggunakan pola dasar Rancangan Acak Kelompok (RAK) dengan tiga kali ulangan. Faktor pertama adalah dosis pupuk organik kascing dengan 4 taraf yaitu K0: Kontrol (tanpa pemberian pupuk organik kascing), K1: 3 ton/ha (120 g/tanaman), K2: 6 ton/ha (240 g/tanaman), K3: 9 ton/ha (360 g/tanaman). Faktor kedua yaitu konsentrasi hormon giberelin dengan 4 taraf yaitu G0 (0 ppm), G1 (50 ppm), G2 (100 ppm) dan G3(150 ppm).

Setiap perlakuan dikombinasikan menjadi 8 kombinasi perlakuan yang diulang sebanyak 3 kali, sehingga jumlah keseluruhan percobaan terdiri dari 48 percobaan. Data yang diperoleh dianalisis menggunakan ANOVA (Analisys of Varians) dan apabila hasil dari sidik ragam menunjukkan pengaruh nyata maka akan dilanjutkan uji lanjut Duncan Multipe Range Test (DMRT) dengan taraf kepercayaan 95\%.

\section{Prosedur Pelaksanaan Percobaan}

Analisis Kandungan Pupuk Organik Kascing dan Tanah. Analisis dilakukan di awal untuk mengetahui beberapa sifat kimia pupuk organik kascing dan sifat fisika tanah yang akan digunakan untuk penelitian. Analisis sifat kimia yang dilakukan pada pupuk kascing yaitu terdiri dari kandungan $\mathrm{N}$-total, $\% \mathrm{P}_{2} \mathrm{O}_{5}, \% \mathrm{~K}, \mathrm{pH}, \%$ Bahan Organik, \% C-Organik, \% Kadar air. Analisis juga dilakukan pada beberapa sifat kimia tanah yang digunakan sebagai media tanam yaitu terdiri $\mathrm{pH}, \mathrm{N}$-total, $\% \mathrm{P}_{2} \mathrm{O}_{5}, \% \mathrm{~K}$ dan $\% \mathrm{C}$. Analisis sifat kimia pupuk kascing dan tanah dilakukan di Laboratorium Puslitkoka Renteng, Rambipuji, Kabupaten Jember.

Tabel 1. Hasil Analisis Pupuk Organik Kascing

\begin{tabular}{llll}
\hline \multicolumn{1}{c}{ Jenis Analisis } & Satuan & Nilai & \multicolumn{1}{c}{ Metode } \\
\hline $\mathrm{pH}$ & - & 7,49 & $\mathrm{pH}$ meter \\
Nitrogen $(\mathrm{N})$ & $\%$ & 1,11 & Titrimetri \\
$\mathrm{P}_{2} \mathrm{O}_{5}$ & $\%$ & 1,28 & Spektrofotometer \\
Kalium $(\mathrm{K})$ & $\%$ & 1,06 & F-AAS \\
$\mathrm{C}$-organik & $\%$ & 21,09 & Pengabuan Kering \\
$\mathrm{C} / \mathrm{N}$ & - & 19,00 & Perhitungan \\
Bahan Organik & $\%$ & 36,35 & Pengabuan Kering \\
Kadar air & $\%$ & 35,09 & Pengabuan Kering \\
\hline
\end{tabular}

Penyiapan Benih. Benih yang digunakan adalah benih mentimun varietas Wuku. Penyiapan benih dilakukan dengan memilih benih yang tidak cacat, kemudian benih direndam dalam air bersuhu $\pm 50^{\circ} \mathrm{C}$ selama $12 \mathrm{jam}$.

Persiapan Media Tanam. Persiapan media tanam diawali dengan mempersiapkan tanah. Tanah yang akan digunakan dikering anginkan terlebih dahulu kemudian ditempatkan pada 
polybag yang berukuran $40 \mathrm{~cm}$ x $40 \mathrm{~cm}$. Pada penelitian ini berat massa tanah yang digunakan untuk 1 polybag yaitu seberat $12 \mathrm{~kg}$. Pemberian pupuk organik kascing diberikan diawal dengan pemberian dosis yang telah disesuiakan dengan perlakuan.

Pemupukan. Pupuk yang digunakan yaitu pupuk Urea, SP36 dan $\mathrm{KCl}$. Pemberian pupuk tunggal anorganik diberikan sebagai pupuk dasar sesuai dengan dosis rekomendasi pemupukan untuk tanaman mentimun lokal yaitu $40 \mathrm{~kg} / \mathrm{ha}$ untuk setiap masingmasing pupuk (Cahyono, 2003), sehingga didapatkan dosis pupuk dasar yaitu sebanyak 1,6 gram/tanaman untuk pupuk Urea, SP-36 dan $\mathrm{KCl}$. Pemberian pupuk dasar dilakukan 1 minggu sebelum tanam.

Penanaman. Melakukan penanaman benih mentimun langsung pada media tanam dengan kedalaman $0,5-1,0 \mathrm{~cm}$, setiap polybag berisi 2 benih. Menempatkan benih dibagian tengah polibag. Benih yang telah tumbuh berumur 14 HST yaitu ditandai dengan pertumbuhan daun yang telah mencapai 3-4 helai daun, akan dicabut salah satunya untuk meninggalkan satu tanaman dalam satu polybag.

Pemupukan. Pemupukan sebelum penanaman perlu dilakukan untuk menyiapkan tanah pada kondisi sebaik mungkin.Pupuk vermikompos digunakan sebagai pupuk dasar bersamaan dengan media tanam.Pupuk TSP dan KCL diberikan sekaligus pada saat tanam, disebarkan dan dicampur rata dengan tanah. pupuk Urea dan ZA diberikan 2 kali, masing-masing setengah dosis, yaitu pada umur 1 dan 4 minggu setelah tanam. Pupuk diaplikasikan melingkar disekeliling tanaman kemudian ditutup dengan tanah.

Aplikasi Hormon Giberelin. Aplikasi hormon giberelin diberikan pada tanaman mentimun dilakukan pada saat tanaman berumur 21 HST yaitu saat tanaman mentimun menjelang fase pembungaan. Penyemprotan dilakukan pukul 06.00 pagi hari. Pengaplikasian hormon ini disemprotkan pada bagian seluruh bagian tanaman. Giberelin $\left(\mathrm{GA}_{3}\right)$ yang digunakan dalam penelitian ini adalah hormon Giberelin berupa tablet seberat 1 gram dengan kandungan bahan aktif sebesar $20 \%$, dimana volume semprot diberikan sebanyak $20 \mathrm{ml} /$ tanaman.

Pemanenan. Pemanenan dilakukan ketika tanaman telah menghasilkan buah. Tanaman mentimun dapat dipanen pada umur 34-35 HST. Pada mentimun varietas Wuku, pemanenan pertama dilakukan pada umur 38HST. Pemanenan pada buah mentimun dilakukan sebanyak 3 kali panen. Kriteria panen untuk varietas Wuku dilakukan pada buah yang telah berbentuk sempurna yaitu bulat panjang dan berwarna hijau dengan semburat kuning kecoklatan (Kementan, 2008).

Variabel pengamatan. Variabel pengamatan meliputi persentase Fruitset (\%), rata-rata bobot buah (g), bobot total buah pertanaman $(\mathrm{g})$, panjang buah $(\mathrm{cm})$, diameter buah $(\mathrm{cm})$.

\section{HASIL DAN PEMBAHASAN}

Rangkuman nilai F-Hitung pengaruh dosis pupuk organik kascing dan konsentrasi hormon giberelin terhadap produksi dan kualitas buah mentimun tersaji dalam Tabel 2.

Tabel 2. Rangkuman Nilai F-hitung Hasil Analisis Ragam pada Semua Variabel Pengamatan

\begin{tabular}{|c|c|c|c|c|}
\hline \multirow[b]{2}{*}{ No } & \multirow{2}{*}{$\begin{array}{c}\text { Variabel } \\
\text { Pengamatan }\end{array}$} & \multicolumn{3}{|c|}{ F-Hitung } \\
\hline & & $\begin{array}{l}\text { Dosis Pupuk } \\
\text { Kascing (K) }\end{array}$ & $\begin{array}{c}\text { Hormon } \\
\text { Giberelin (G) }\end{array}$ & Interaksi \\
\hline 1 & $\begin{array}{l}\text { Persentase } \\
\text { Fruitset }(\%)\end{array}$ & $4,96 * *$ & $3,03 *$ & $1,24^{\mathrm{ns}}$ \\
\hline 2 & $\begin{array}{l}\text { Rata-Rata Bobot } \\
\text { Buah (g) }\end{array}$ & $5,87 * *$ & $4,02 *$ & $1,16^{\mathrm{ns}}$ \\
\hline 3 & $\begin{array}{l}\text { Bobot Total } \\
\text { Buah }(\mathrm{g})\end{array}$ & $11,01 * *$ & $1,93^{\mathrm{ns}}$ & $1,21^{\mathrm{ns}}$ \\
\hline 4 & $\begin{array}{l}\text { Panjang Buah } \\
(\mathrm{cm})\end{array}$ & $5,11 * *$ & $5,12 * *$ & $2,39 *$ \\
\hline 5 & $\begin{array}{l}\text { Diameter Buah } \\
(\mathrm{cm})\end{array}$ & $2,82^{\mathrm{ns}}$ & $5,55 * *$ & $0,85^{\mathrm{ns}}$ \\
\hline
\end{tabular}

Keterangan: **( berbeda sangat nyata), * (berbeda nyata), ns (berbeda tidak nyata)
Berdasarkan Tabel 1 menunjukkan bahwa interakasi antar perlakuan dosis pupuk organik kascing dan hormon giberelin hanya memberikan pengaruh berbeda nyata pada variabel panjang buah. Pengaruh faktor tunggal perlakuan dosis pupuk organik kascing memberikan pengaruh sangat nyata pada variabel persentase fruitset, rata-rata bobot buah, bobot total buah pertanaman dan panjang buah, sednagkan memberikan pengaruh berbeda tidak nyata pada variabel diameter buah. Konsentrasi hormon giberelin memberikan pengaruh berbeda nyata variabel persentase fruitset, rata-rata bobot buah dan serta pengaruh berbeda sangat nyata pada variabel panjang buah dan diameter buah.

Interaksi antara Kombinasi Dosis Pupuk Organik Kascing dan Konsentrasi Hormon Giberelin terhadap Panjang Buah Mentimun

Berdasarkan hasil sidik ragam (Tabel 4.4) menunjukkan pada variabel panjang buah terdapat interaksi berbeda nyata dari kombinasi dosis pupuk kascing dan hormon giberelin, sehingga dilakukan uji lanjut DMRT pada taraf 5\% dengan hasil sebagai berikut:

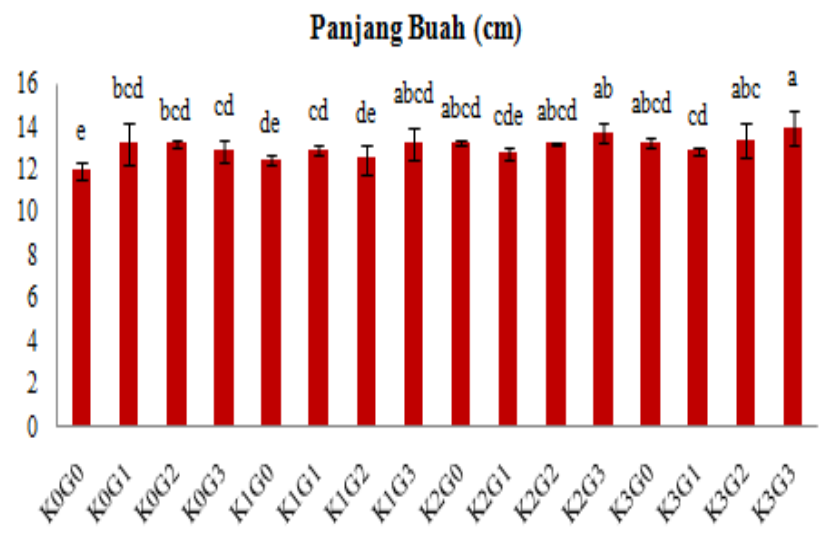

Gambar 1. Hasil Uji Lanjut Interaksi Perlakuan Pupuk Kascing dan Hormon Giberelin terhadap Panjang Buah Mentimun

Keterangan: Angka yang diikuti notasi huruf yang sama menunjukkan pengaruh interaksi dosis pupuk kascing $(\mathrm{K})$ dengan konsentrasi hormon giberelin $(G)$ yang tidak berbeda nyata pada variabel panjang buah.

Berdasarkan hasil percobaan rerata panjang buah mentimun terbaik yaitu pada kombinasi perlakuan K3G3 yaitu sebesar 13,99 $\mathrm{cm}$, sedangkan terendah yaitu pada perlakuan K0G0 yaitu hanya sebesar 11,97 cm. Apabila dibandingkan dengan deskripsi panjang buah untuk varietas wuku dengan memiliki potensi panjang buah $12-13 \mathrm{~cm}$, maka dapat dikatakan hasil percobaan ini memiliki hasil yang melebihi dari standar panjang buah untuk varietas Wuku.

Pengaruh Faktor Tunggal Dosis Pupuk Kascing (K) dan Hormon Giberelin $\left(\mathbf{G A}_{3}\right)$ terhadap Hasil Produksi dan Kualitas Buah Mentimun (Cucumis sativus L.)

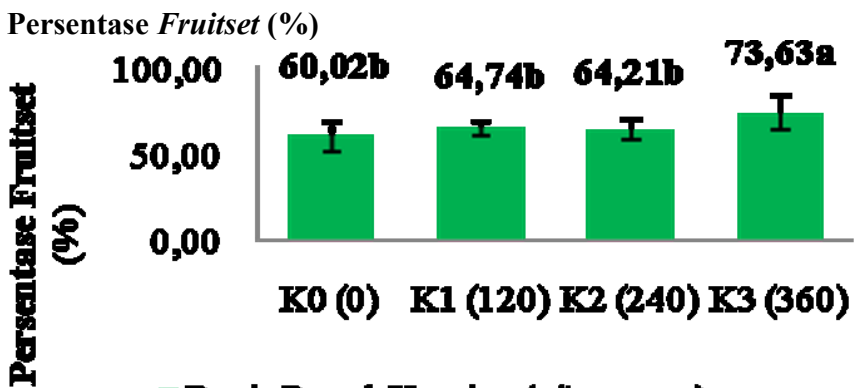

Dosis PupukKascing (g/tanaman)

Gambar 2. Pengaruh Dosis Pupuk Kascing terhadap Persentase Fruitset Tanaman Mentimun 
Gambar 2 menunjukkan pada perlakuan dosis pupuk kascing $360 \mathrm{~g} /$ tanaman memiliki nilai hasil rata-rata persentase Fruitset tertinggi yaitu $73,63 \%$ dan hasil persentase terendah pada perlakuan $0 \mathrm{~g} / \operatorname{tanaman}(\mathrm{K} 0)$ yaitu sebesar $60,02 \%$.
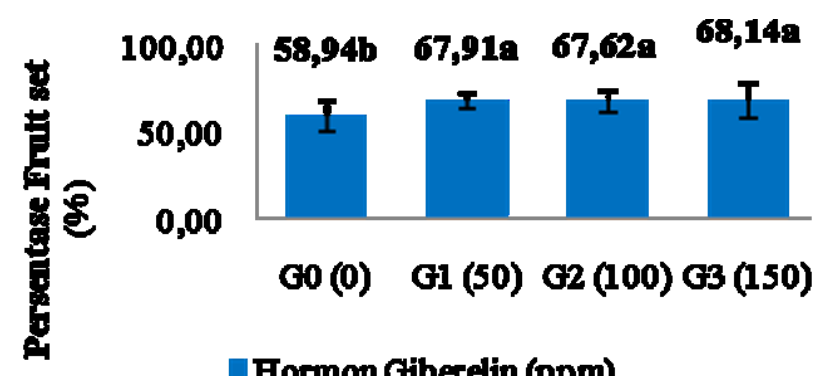

G0 (0) G1 (50) G2 (100) G3 (150)

\section{Hormon Giberelin (ppm)}

Gambar 3. Pengaruh Konsentrasi Hormon Giberelin terhadap Persentase Fruitset Tanaman Mentimun

Variabel persentase fruitset juga dipengaruhi oleh faktor pemberian konsentrasi hormon giberelin. Gambar 3 menunjukkan pengaruh konsentrasi hormon giberelin memberikan hasil rata-rata persentase Fruitset tertinggi pada perlakuan 150 ppm (G3) yaitu sebesar $68,14 \%$ dan tidak berbeda nyata dengan perlakuan 100 ppm (G2) yaitu dengan persentase sebesar 67,62\%. Hasil terendah ditunjukkan yaitu pada perlakuan kontrol 0 ppm (G0) dengan nilai persentase Fruitset 58,94\%.

\section{Rata-Rata Bobot Buah Mentimun (g)}
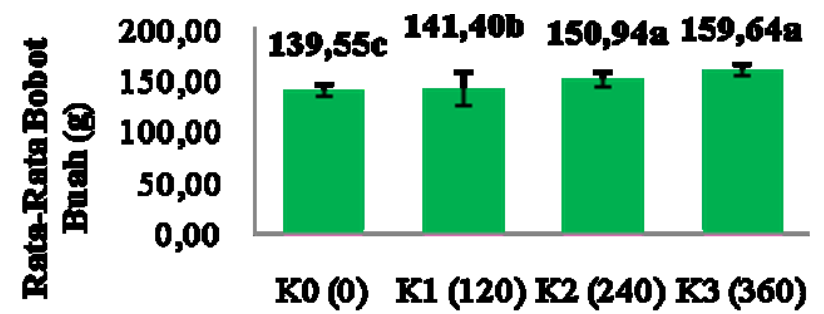

\section{Dosis PupukKascing (o/tanaman)}

Gambar 4. Pengaruh Dosis Pupuk Kascing terhadap Rata-Rata Bobot Buah Mentimun

Ganbar 4 menunjukkan pemberian pupuk organik kascing memberikan pengaruh berbeda sangat nyata terhadap hasil rata-rata bobot buah mentimun. Hasil tertinggi ditunjukkan oleh perlakuan pemberian dosis pupuk organik kascing $360 \mathrm{~g} / \operatorname{tanaman}(\mathrm{K} 3)$ yaitu sebesar 159,64 gram, sedangkan hasil terendah yaitu pada perlakuan K0 dengan hasil sebesar 139,55 gram.

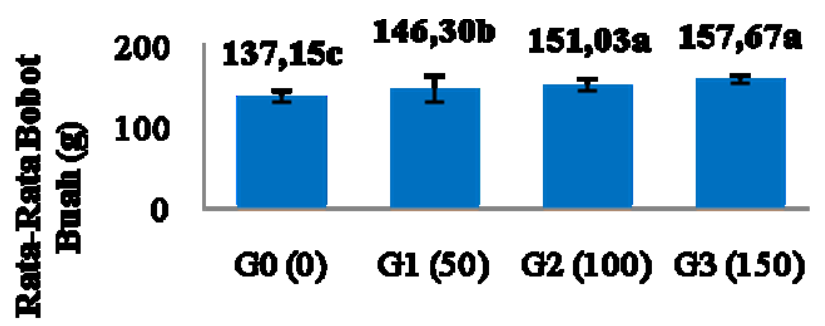

\section{Hormon Giberelin (ppm)}

Gambar 5. Pengaruh Hormon Giberelin terhadap Rata-Rata Bobot Buah Mentimun

Gambar 5 menunjukkan pengaruh konsentrasi hormon 150 ppm (G3) memberikan hasil tertinggi pada rata-rata bobot buah mentimun yaitu sebesar 157,67 gram, namun hal ini tidak berbeda nyata pada perlakuan 100 ppm (G2) dengan hasil sebesar 151,03 gram. Hasil terendah ditunjukkan pada perlakuan $0 \mathrm{ppm}(\mathrm{G} 0)$ yaitu dengan hasil sebesar 137,15 gram.
Total Bobot Buah Pertanaman (g)

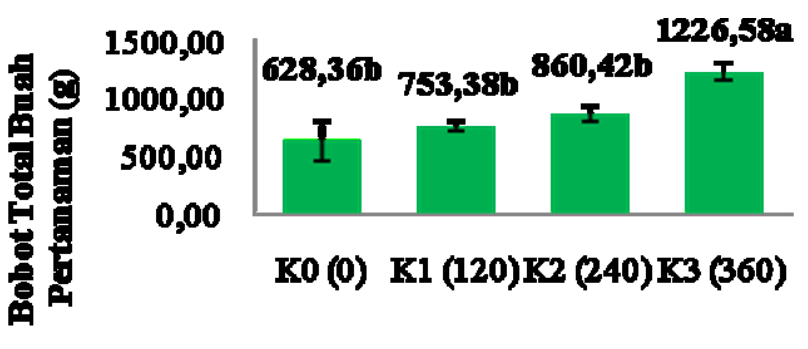

\section{Dosis PupukKascing (oftanaman)}

Gambar 6. Pengaruh Dosis Pupuk Kascing terhadap Total Bobot Buah Pertanaman

Gambar 6 menunjukkan pengaruh faktor tunggal pemberian pupuk organik kascing berpengaruh sangat nyata terhadap bobot total buah pertanaman. Hasil tertinggi terdapat pada perlakuan pemberian pupuk orgnik kascing sebanyak $360 \mathrm{~g} / \operatorname{tanaman}(\mathrm{K} 3)$ dengan hasil sebesar 1226,58 gram. Sedangakan pada ketiga perlakuan lainnya menunjukkan hasil yang tidak berbeda nyata, dimana hasil terendah ditunjukkan pada perlakuan tanpa pemberian pupuk kascing (K0) yaitu sebesar 628, 36 gram. Apabila dikonversikan kedalam satuan produksi dalam hektar maka didapatkan hasil pada perlakuan dosis 0 gram/tanaman (K0) 15.709 $\mathrm{kg} \quad(15,7$ ton/ha), perlakuan dosis $120 \mathrm{~g} / \operatorname{tanaman}$ (K1) menghasilkan $18.384 \mathrm{~kg}(18,3 \mathrm{ton} / \mathrm{ha})$, perlakuan dosis 240 $\mathrm{g} /$ tanaman (K2) menghasilkan $21.500 \mathrm{~kg}$ (21,5 ton/ha) dan perlakuan terbaik dosis pupuk kascing $360 \mathrm{~g} / \operatorname{tanaman}(\mathrm{K} 3)$ yaitu sebesar $30.664 \mathrm{~kg}(30,6 \mathrm{ton} / \mathrm{ha})$.

Diameter Buah Mentimun

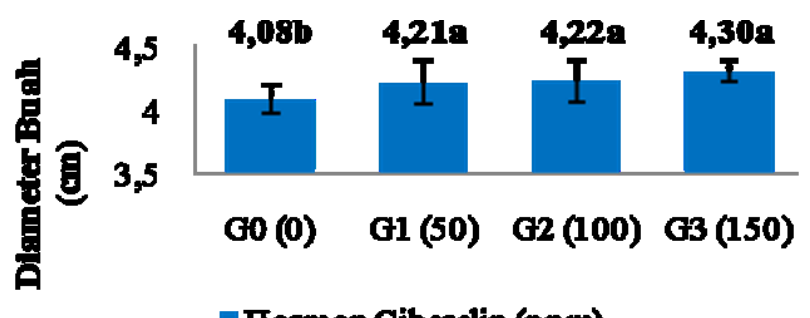

"Hormon Giberelin (ppm)

Gambar 7. Pengaruh Hormon Giberelin terhadap Diameter Buah Mentimun

Gambar 7 menunjukkan konsentrasi hormon giberlin meberikan pengaruh berbeda sangat nyata dengan hasil diameter buah tertinggi yaitu pada perlakuan $150 \mathrm{ppm}(\mathrm{G} 3)$ sebesar $4,30 \mathrm{~cm}$ dan tidak berbeda nyata dengan perlakuan 50 ppm (G1) dan 100 ppm (G2), sedangkan hasil terendah pada perlakuan 0 ppm (G0) yaitu sebesar $4,08 \mathrm{~cm}$.

Pada percobaan ini hasil produksi buah mentimun Wuku ditunjukkan oleh parameter rata-rata bobot buah dan rata-rata total bobot buah pertanaman yang terbaik yaitu pada perlakuan dosis pupuk kascing $360 \mathrm{~g} /$ tanaman yang menghasilkan rata-rata bobot buah pada perlakuan (K3) yaitu sebesar 159,64 gram dengan ratarata total bobot buah pertanaman sebesar $30.664 \mathrm{~kg}(30,6 \mathrm{ton} / \mathrm{ha})$.

Parameter hasil tanaman mentimun yaitu rata-rata bobot buah dipengaruhi oleh faktor tunggal pemberian dosis pupuk organik kascing dan konsentrasi hormon giberelin, dimana perlakuan terbaik ditunjukkan pada perlakuan dosis pupuk kascing 360 g/tanaman (K3) dengan rata-rata bobot buah sebesar 159,64 gram. Bobot segar tanaman atau berat segar hasil dapat dipengaruhi oleh kadar air jaringan, ketersediaan unsur hara dan respon metabolisme tanaman (Salisbury dan Ross, 1995). Pemberian pupuk organik kascing diduga mampu meningkatkan kandungan unsur $\mathrm{P}$ dan $\mathrm{K}$ yang berguna untuk masa vegetatif dan generatif tanaman (Belliturk et al, 2017). Fungsi unsur P dapat meningkatkan hasil buah karena fosfor berguna untuk membentuk protein, mineral dan 
karbohidrat dalam buah. Selain itu peran unsur kalium berfungsi untuk translokasi karbohidrat dan pembentukan pati dan juga dapat meningkatkan translokasi fotosintat dari organ source seperti daun menuju buah untuk perkembangan buah sehingga bobot buah bertambah. Hal ini sesuai dengan penelitian Ghasem et al (2014), bahwa dengan penambahan 14 ton/ha pupuk organik kascing memberikan hasil yang signifikan terhadap bobot buah mentimun.

Perlakuan konsentrasi hormon giberelin memberikan pengaruh terhadap bobot buah mentimun, dimana ditunjukkan pada Gambar 5 bobot buah meningkat seiring dengan peningkatan konsentrasi hormon giberelin. Pemberian hormon giberelin secara eksogen berfungsi untuk transportasi dan akumulasi fotosintat yang diarahkan untuk perkembangan buah dan memberikan pengaruh yang signifikan terhadap pembelahan sel dan meningkatkan ukuran buah yang lebih besar (El Sherif et al, 2017). Menurut Megbo (2010), peningkatan berat buah juga dikarenakan adanya pembesaran dan pembelahan sel serta peningkatan ruang antar sel dalam sel bagian mesocarpic.

Proses-proses fisiologi yang berlangsung pada tanaman memiliki pengaruh yang saling berkaitan terhadap produksi atau hasil suatu tanaman, dimana proses fisiologi tersebut berlangsung baik pada fase vegetatif dan generatif tanaman. Salah satu variabel pengamatan yang berpengaruh terhadap produksi buah mentimun yaitu dapat dilihat dari persentase fruitset. Pada perlakuan pemberian pupuk kascing $360 \mathrm{~g} / \operatorname{tanaman}$ (K3) memberikan hasil terbaik dengan persentase fruitset sebesar $73,63 \%$. Banyak faktor yang mempengaruhi tingkat keberhasilan dari pembentukan bunga menjadi buah, dimana buah menjadi salah satu organ sink dalam perkembangannya. Menurut Fischer et al (2012), selama perkembangan bunga menjadi buah didasari oleh adanya beberapa faktor yaitu seperti rasio daun dan buah, genetik, faktor iklim, jumlah cabang pada tanaman, umur tanaman dan pasokan nutrisi. Salah satu unsur hara yang mempengaruhi pembentukan buah yaitu fosfor dan kalium.

Selain pengaruh dosis pupuk organik kascing, pemberian konsentrasi hormon giberelin juga memberikan pengaruh nyata terhadap peningkatan persentase fruitset tanaman mentimun. Hasil terbaik ditunjukkan oleh perlakuan konsentrasi $150 \mathrm{ppm}$ (G3) dengan hasil persentase fruitset sebesar $68,14 \%$, namun tidak berbeda nhyata dengan perlakuan $100 \mathrm{ppm}$ (G2) yang menghasilkan persentase fruitset sebesar $67,62 \%$. Tanaman yang memiliki fitohormon yang cukup akan menjadikan organ sink salah satunya buah akan menerima dengan kuat zat-zat metabolit yang dihasilkan dari bagian tanaman lainnya (source), sehingga akan menjamin keberlangsungan pertumbuhan dan perkembangan bunga menjadi buah yang sempurna. Dalam mengontrol fruitset hormon giberelin saling bersinergi dengan auksin. Adanya penyerbukan dan pemupukan menghasilkan peningkatan kadar auksin dan giberelin yang memicu pertumbuhan buah melalui stimulasi pembelahan sel (Ruan et al, 2012).

Pada hasil kualitas buah ditunjukkan dengan variabel pengamatan panjang buah dan diameter buah. Pada variabel panjang buah menunjukkan adanya interaksi antara kombinasi perlakuan pemberian dosis pupuk kascing dan konsentrasi hormon giberelin. Hasil pengamatan menunjukkan bahwa pada kombinasi K3G3 menghasilkan panjang buah tertinggi. Adanya interaksi tersebut dikarenakan dalam perkembangan organ-organ tanaman, tanaman membutuhkan unsur hara dan juga hormon baik endogen maupun dengan penambahan hormon eksogen untuk menghasilkan pertumbuhan dan hasil tanaman yang optimal. Hal ini sesuai dengan pernyataan Kumari et al (2018), bahwa perkembangan buah melalui cara dan tahap perkembangan yang berbeda-beda, perkembangan buah merupakan proses yang diatur oleh beberapa faktor karena buah sangat aktif dalam masa perkembangannya secara metabolik yang mampu bertindak sebagai organ source yang kuat untuk nutrisi dan hormon yang berfungsi sebagai pendukung proses perkembangan buah.

Pemupukan dengan bahan organik merupakan salah satu upaya dalam pemenuhan unsur hara pada tanah, memperbaiki tingkat kesuburan tanah dan dapat mendukung produksi tanaman. Pemberian kascing dapat meningkatkan kebutuhan unsur N, P dan
$\mathrm{K}$ dalam tanah, dimana unsur tersebut digunakan untuk proses fotosintesis sebagai penyusun karbohidrat, lemak, protein, mineral dan vitamin yang ditranslokasikan ke bagian buah. Unsur $\mathrm{P}$ dibutuhkan untuk perkembangan buah, unsur fosfor berfungsi untuk penyimpanan dan transfer energi selain itu juga sebagai sumber energi untuk perkembangan tanaman seperti pembelahan sel, pembentukan enzim, respirasi dan fotosintesis (Hariyadi, 2015). Fosfor yang terserap dalam bentuk anion yaitu $\mathrm{H}_{2} \mathrm{PO}_{4}^{-}$akan dikonversi dalam bentuk gula fosfat, nukleotida, RNA atau DNA yang dibutuhkan dalam pembelahan serta pembesaran sel (Lakitan, 2011). Hal ini memungkinkan untuk memacu perkembangan panjang buah mentimun. Pada kandungan pupuk organik kascing yang digunakan, kandungan unsur $\mathrm{P}$ memiliki kadar yang paling tinggi yaitu sebesar $1,28 \%$.

Hormon giberelin juga berpengaruh terhadap hasil panjang buah mentimun maupun diameter buah. Sesuai dengan pernyataan Soliman and Ali (2009), beberapa konsentrasi giberelin memberikan respon terhadap penambahan ukuran diamter buah, panjang, dan bobot daging buah. Perkembangan buah, giberelin akan menginduksi pembelahan dan pembentangan sel pada bagian perikarpi bakal buah, pada buah mentimun hanya memiliki dua bagian yaitu eksokarpi dan mesokarpi, dimana pembentangan dan pembelahan sel terjadi pada bagian mesokarpi buah sehingga terjadi peningkatan ukuran atau bobot buah. Giberelin memiliki fungsi untuk mendukung perpanjangan sel, pembelahan sel, pembentukan RNA dan protein sehingga mendorong perkembangan organ tanaman. Pemanjangan sel terjadi karena giberelin meransang terbentuknya enzim amilase yang akan menghidrolisis pati sehingga kadar gula dalam sel akan naik dan menyebabkan air lebih banyak masuk ke sel sehingga sel memanjang (Ridwansyah dan Wibowo, 2016).

\section{KESIMPULAN}

1. Terdapat interaksi kombinasi antara perlakuan dosis pupuk kascing dengan konsentrasi hormon giberelin terhadap variabel panjang buah mentimun.

2. Perlakuan dosis pupuk kascing memberikan pengaruh sangat nyata terhadap parameter produksi buah mentimun yaitu ratarata bobot buah dan bobot total buah serta memberikan pengaruh nyata terhadap parameter kualitas buah yaitu panjang buah. Hasil terbaik yaitu pada perlakuan dosis pupuk kascing $360 \mathrm{~g} /$ tanaman atau setara dengan 9 ton/ha (K3).

3. Perlakuan konsentrasi hormon giberelin memberikan pengaruh nyata terhadap paramater produksi buah yaitu rata-rata bobot buah dan berpengaruh sangat nyata pada parameter kualitas buah yaitu diameter buah dan panjang buah serta berpengaruh nyata pada tebal daging buah dengan konsentrasi optimal yaitu pada perlakuan konsentrasi 100 ppm (G2).

\section{DAFTAR PUSTAKA}

Abdurrazak, M. Hatta dan A. Marliah. 2013. Pertumbuhan dan Hasil Tanaman Mentimun (Cucumis sativus L.) Akibat Perbedaan Jarak Tanam dan Jumlah Benih Per Lubang Tanam. Agrista, 17(2): 55-59.

Belliturk, K., S. Adiloglu, Y. Solmaz, A. Zahmacioglu and A. Adiloglou. 2017. Effect of Increasing Doses of Vermicompost Applications on P and K Content of Pepper (capsicum annuum L.) and Eggplant (Solanum melongena L.). Advanced Agricultural Technologies, 4(4): 372-375.

Direktorat Jendral Hortikultura. 2015.Statistik Produksi Hortikultura Tahun 2014. Jakarta: Direktorat Jendral Hortikultura.

El Sherif, A. R.,A. E Zaghloul, and D. M. A. Elyazid. 2017. Effect of Sreaptomycin and GA3 Application on Seedlessnes, Yield and Fruit Quality of Balady Mandarin. 2017. Egypt J. Hort, 44(1): 99-104. 
Fischer, G., P. J. A. Merchan and F. Ramirez. 2012. Source - Sink Relationship in Fruit Species - A Review. Revista Colombianan de Ciencias Horticolas, 6(2): 238-253.

Ghasem, S., A. S. Morteza and T. Maryam. 2014. Effect of Organic Fertilizers on Cucumber (Cucumis sativus) Yield. Agriculture and Crop Sciences, 7(11): 808-814.

Haryadi, D., H. Yetti dan S. Yoseva. 2015. Pengaruh Pemberian Beberapa Jenis Pupuk terhadap Pertumbuhan dan Produksi Tanaman Kailan (Brassica alboglabra L.). Jom Faperta, 2(2): $1-10$.

Kumari, S., P. Bakshi, A. Sharma, V. K. Wali, A. Jastirotia and S. Kour. 2018. Use of Plant Growth Regulators for Improving Fruit Production in Sub Tropical Crops. Current Microbiology and Applied Sciences, 7(3): 659-668.

Lakitan. 2011. Dasar-Dasar Fisiologi Tumbuhan. Jakarta: PT. Raja Grafindo Persada.

Megbo. B. C. 2010. Control of Fruit Drop and Development in Tomato, Lycopersicum esculentum Mill, Using Plant Growth Regulators. Scientific and Engineering Research, 1(1): 10-15.

Permanasari, I. dan A. R. Annisava. 2015. Upaya Peningkatan Hasil Mentimun Secara Organik dengan Sistem Tasalampot. Agroteknologi, 6(1): 17-24.

R. Thiruneelakandan and G. Subbulakshmi. 2014. Vermicomposting: A Superlative For Soil, Plant, and Enviroment. Innovative Research inScience, Engineering and Technology, 3(1): 930-938.

Ridwansyah, A., dan N. I. Wibowo. 2016. Respon Pertumbuhan dan Hasil Tanaman Mentimun (Cucumis sativus L.) terhadap Pemberian RPTT (Rizobakteria Pemacu Tumbuh Tanaman) Akar Putri Malu dan Giberelin. Agroscience, 6(2): 78-87.

Ruan, Y. L., J. W. Patrick, M. Bouzayen, S. Osorio and A. R. Fernie. 2012. Molecular Regulation of Seed and Fruit Set. Trends in Plant Science, 17(11): 1360-1385.

Salisbury, F. B. And C. W. Ross. 1995. Fisiologi Tumbuhan. Bandung: ITB Press.

Simanullang, V., M. K. Bangun dan H. Setiado. 2014. Respon Pertumbuhan Beberapa Varietas Timun (Cucumis sativus L.) Terhadap Pemberian Pupuk Organik. Agroekoteknologi, 2(2): 680-890.

Soliman, S. S., and E. A. M. Ali. 2009. Effect of GA3 on Yield and Fruit Characteristics of Sakkoty Date Palm Under Aswan Conditions in Egypt. Green Farming,2(7): 459-462.

Wulandari, D. C., Y. S. Rahayu dan E. Ratnasari. 2014. Pengaruh Pemberian Hormon Giberelin terhadap Pembentukan Buah Secara Partenokarpi pada Tanaman Mentimun Variets Mercy. Lentera Bio, 3(1): 27-32.

Yasmin, S., T. Wardiyati, dan Koesriharti. 2014. Pengaruh Perbedaan Waktu Aplikasi Dan Konsentrasi Giberelin (GA3) Terhadap Pertumbuhan dan Hasil Tanaman Cabai Besar (Capsicum Annuum L.). Produksi Tanaman, 2(5): 395-403 